\title{
Clastogenic effect of sodium arsenite in experimental rats and ameliorative effects of antioxidant vitamins $\mathrm{C}$ and $\mathrm{E}$
}

\author{
B.S. Balakumar ${ }^{1}$, S. Kumaresan ${ }^{1}$, R.Venugopal ${ }^{2}$ and V. Sivasubramanian ${ }^{1}$ \\ ${ }^{1}$ Department of Plant Biology \& Plant Biotechnology, RKM. Vivekananda College, Mylapore, Chennai -600 004, India \\ ${ }^{2}$ Research Institute of Veterinary Medicine, Chungbuk National University, South korea \\ bsbviveka@gmail.com
}

\begin{abstract}
Arsenic, an element ubiquitous in the environment, causes serious health problems in humans. The general population is more exposed to arsenic through drinking water than through air and food. Sodium arsenite, capable of inducing genotoxic effects through oxidative stress, is evaluated for its clastogenic effect by the formation of chromosomal aberrations in the bone marrow cells of Wistar rats. We also investigated whether the oral supplementation of $\alpha$ tocopherol (400 mg/kg body weight) and ascorbic acid (200 mg/kg body weight) to arsenic-intoxicated rats (100 ppm in drinking water) for 30days, ameliorates arsenic-induced toxicity. We report that the dietary supplementation of antioxidants such as vitamins $\mathrm{C}$ and $\mathrm{E}$ could prevent sodium arsenite induced toxicity in rats under experimental conditions.
\end{abstract}

Keywords: Arsenic, genotoxicity, ascorbic acid, $\alpha$-tocopherol, chromosomal aberrations, vitamins, rat, bone marrow.

\section{Introduction}

Pollution at various levels has modified the global natural events. Of all the types of pollution, contamination due to heavy metals and metalloids, including the toxic nonessential elements like Arsenic, Mercury, Cadmium and Lead is wide spread (Roy and Saha, 2002). Among these metals, arsenic is possibly the most abundant pollutant having a complex metabolism and a classified potential human carcinogen. Arsenic is widely distributed in nature and principally occurs in the form of inorganic or organic compounds. An inorganic arsenical compound consists of arsenite, considered to be the most toxic form, and arsenate the less toxic form, and organic forms the least toxic ones (WHO, 1993). As a result of wide occurrence of arsenic in the environment, human exposure to the metalloid becomes almost universal. The most common pathway for an elevated environmental exposure to inorganic arsenic worldwide is through drinking water. Chronic exposure to arsenic causes a wide range of toxic effects and thus this metalloid is classified as Group I carcinogen in humans (IARC, 1987). Based on substantial evidence on cancer risk associated with chronic exposure to relatively low concentrations of arsenic in drinking water, the international agencies like National Research Council, (NRC, 1999) has suggested $50 \mu \mathrm{g} / \mathrm{l}$ as the Maximum Contaminant Level (MCL) with an increase in risk for cancer. The United States Environment Protection Agency has revised the maximum containment level for arsenic in drinking water as $10 \mu \mathrm{g} / \mathrm{l}$ (USEPA, 2001) and the WHO, has suggested a provisional guide line value of $10 \mu \mathrm{g} / \mathrm{l}$ of arsenic in drinking water and the European union has set $50 \mu \mathrm{g} / \mathrm{l}$ and $10 \mu \mathrm{g} / \mathrm{l}$ as limit and guide values of arsenic in drinking water respectively (WHO, 1981). Chronic arsenicism has been observed in workers and in groups of the general population living in some areas of The United States (Welch et al., 1998; Shaw et al., 2005), United Kingdom (Goyer et al., 1995), China (Luo et al., 1997), Taiwan (Chen et al., 2005; Tseng et al., 2006), Mexico (Cebrian et al., 1993), Chile (Smith et al., 1998), Argentina (Rich et al., 1998), India (Mazumdar, 1988; Rahman et al., 2005) and Bangladesh (Gamble et al., 2005). Note worthy among them are India and Bangladesh where the arsenic concentration in drinking water is hundred times more than the recommended safety level prescribed by the international agencies.

Following ingestion, inorganic arsenic appears rapidly in the circulation, where it binds primarily to hemoglobin (Axelson, 1980). Skin, bone and muscle represent the major storage organs (Osborne, 1925). Inorganic arsenic does not appear to cross the blood brain barrier; however transplacental transfer of arsenic in humans (Gibson and Gage, 1982) and mice (Hood et al., 1987) occurs. The metabolism of arsenic like other toxic metals is associated with the conversion of the most potent toxic form of this element to the less toxic form, followed by cellular accumulation or excretion. Biomethylation of arsenic is considered as the primary detoxification mechanism, since the inorganic arsenics are more toxic to the living organisms (Yamauchi and Fowler, 1994). Arsenic toxicity differs in a fundamental fashion from that of other "Protoplasmic Poison", which acts by denaturing and precipitating the cellular proteins. It has been assumed that the effect of arsenic must depend on a functional activity rather than on structural integrity (Stocken and Thompson, 1946). Arsenicals can cause cellular damage through the generation of free radicals (Barchowsky et al., 1996). Several studies suggest that arsenic compounds may also exert their toxicity through the generation of reactive oxygen species such as
Research article

CIndian Society for Education and Environment (iSee)
"Vitamins to ameliorate arsenic toxicity"

http://www.indjst.org
Balakumar et al. Indian J.Sci.Technol. 
superoxide, hydroxyl radicals, hydrogen peroxide and nitric oxide during their metabolism in the cells (Hei and Filipic, 2004; Liu et al., 2005). Though Arsenicals are unable to induce gene mutation in cultured cells, arsenite has been shown to enhance the cytotoxicity, mutagenicity and clastogenicity of UV-radiation, alkylating and DNA crosslinking agents in rodents and human cells (Lee et al., 1986; Okui and Fujiwara, 1986). Genotoxic studies of arsenic have largely yielded negative findings for gene mutations but positive results for chromosomal aberrations (Lee et al., 1996). Therefore the present study was aimed to study whether supplementation of antioxidants such as vitamin $\mathrm{C}$ and $\mathrm{E}$, prevent sodium arsenite induced clastogenicity in experimental rats.

\section{Material and Methods}

Male albino rats of Wistar stain (120-150 g) were used in this study. The animals were obtained from The King Institute of Preventive Medicine, Chennai. The animals were housed in large spacious cages and were given food and water ad libitum. The animal room was well ventilated with a $12 \mathrm{~h}$ light/dark cycle, throughout the period of the experiment. The animals were maintained on a commercial rat-feed manufactured by Hindustan Lever Ltd., Mumbai under the trade name "gold mohur rat feed". The feed contained $5 \%$ fat, $21 \%$ protein, $55 \%$ nitrogen free extract and $4 \%$ fibre with adequate mineral and vitamin contents (Anusuyadevi et al., 2008).

\section{Grouping of animals}

The animals were divided into five groups, namely, Group I: Rats that received vehicles alone, (served as control).

Group II: Rats that received arsenic as sodium arsenite in drinking water at a concentration of $100 \mathrm{ppm}$.

Group III: Rats that were treated with arsenic along with ascorbic acid ( $200 \mathrm{mg} / \mathrm{kg}$ body wt. dissolved in water) given by oral gavage once a day.

Group IV: Rats that were given arsenic along with $\alpha$ tocopherol $(400 \mathrm{mg} / \mathrm{kgbody}$ wt. dissolved in mineral oil) by oral gavage once a day.

Group V: Rats that were administered arsenic along with ascorbic acid ( $200 \mathrm{mg} / \mathrm{kg}$ body wt. dissolved in water) and $\alpha$-tocopherol $(400 \mathrm{mg} / \mathrm{kg}$ body wt. dissolved in mineral oil) by oral gavage once a day.

Food and water intake and body weight of the animals were monitored throughout the 30 days of the period of the experiment.

\section{Estimation of arsenic}

Tissue/blood/urine samples were digested according to the method of Ballentine and Burford (1957). To 100 $\mathrm{mg}$ of tissues $/ 1 \mathrm{ml}$ of blood or urine, $1 \mathrm{ml}$ of concentrated nitric acid was added, followed by $1 \mathrm{ml}$ of perchloric acid. The sample was then digested over a sand bath until the solution turned yellow in colour. If the colour of the digest was brown, more nitric acid and perchloric acid were added and the oxidation was repeated. The digest was made up to known volume with deionized water. Aliquots of this were used to estimate arsenic by using the atomic absorption spectrophotometer. The concentration of arsenic was expressed as $\mu \mathrm{g} / \mathrm{dl}$ blood or $\mu \mathrm{g} / \mathrm{g}$ tissue.

\section{Assessment of chromosomal aberration}

Chromosomal aberrations were assessed by the method of Sharma and Sharma (1994). After 30 days of the experimental period, colchicine $(0.15 \mathrm{ml})$ was administered intra-peritoneal to the animals $90 \mathrm{~min}$ before sacrifice. The animals were killed by cervical dislocation. Bone marrow cells from control and experimental animals were processed for analysis of chromosomal aberrations. The bone marrow from the femurs was flushed into a centrifuge tube containing $0.9 \%$ saline and centrifuged at $500 \mathrm{~g}$ for $5 \mathrm{~min}$. The supernatant was removed and hypotonic $\mathrm{KCl}$ was added to the sediment. After incubation for $20 \mathrm{~min}$ at $37^{\circ} \mathrm{C}$, the contents were centrifuged for $5 \mathrm{~min}$ and the sediment was fixed in methanol-acetic acid $(3: 1 \mathrm{v} / \mathrm{v})$. Three changes of fixative were given prior to slide preparation. The slides were airdried, stained with Giemsa solution. This stock was prepared from $1 \mathrm{~g}$ of Giemsa dissolved in $56 \mathrm{ml}$ of glycerol, kept on a magnetic stirrer for an overnight at $50^{\circ} \mathrm{C}$. On cooling to room temperature, $84 \mathrm{ml}$ of methanol was added and kept again on the magnetic stirrer for 60 $\min$. The filtrate was then stored in dark colour bottles and stored at $0-4^{\circ} \mathrm{C}$. Working stain solution was prepared by mixing $2 \mathrm{ml}$ of $10 \%$ di-sodium hydrogen phosphate and $2 \mathrm{ml}$ of stock and made up to $50 \mathrm{ml}$ with double distilled water. The slides were then scored blindly with oil-immersion magnification in a light microscope.

The diploid number of chromosomes in a rat is 42 . The chromosomes are classified into three major groups and one sex pair. Group A consists of four pairs, each pair is morphologically distinct, group $B$ consists of nine pairs in a gradation of length, group $C$ consists of meta and sub-metacentrics constituting seven pairs. All these pairs are relatively short and are similar in morphology and the sex pair consists of a medium sized acrocentric $X$-chromosome and an acrocentric $Y$ chromosome, which is slightly shorter than chromosome no. 9 (Miller et al., 1972; Unakul and Hsu,1977). One hundred well scattered metaphase plates were scored for each animal, giving a total of 1000 metaphases per group. Aberrations like breaks, gaps, deletions, fragments are recorded.

\section{Statistical analysis}

Values are expressed as mean \pm SD for six rats in each group, and significance of the differences between mean values were determined by one way analysis of variance (ANOVA) followed by Duncan test for multiple comparison using statistical package for social sciences (SPSSS) version 11.0 package. Values of $p<0.05$ were considered to be significant. Correlation analysis was done using statistical package Statistica/w 5.0 for windows.
Research article

CIndian Society for Education and Environment (iSee)
"Vitamins to ameliorate arsenic toxicity" http://www.indjst.org
Balakumar et al. Indian J.Sci.Technol. 
Fig. 1. Shows the levels of chromosomal aberrations

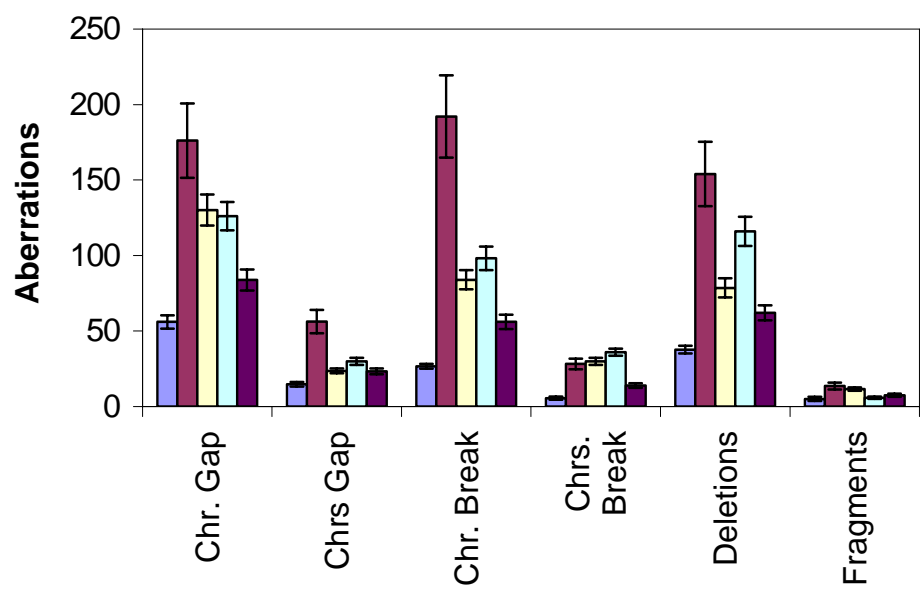

In each end-point study, the column 1, 2, 3, 4 and 5 in a row represents Group I, II, III, IV and V, respectively.

Fig. 2. Chromosome aberration types

Chromatid gap

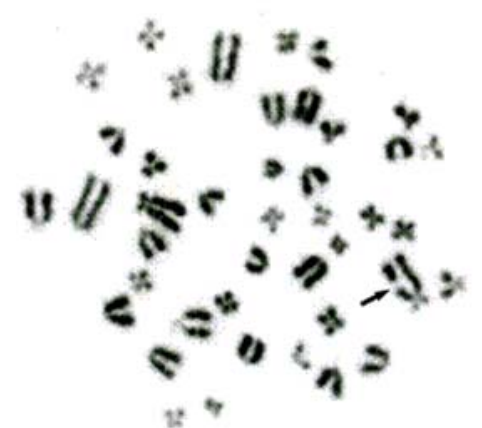

Chromatid break

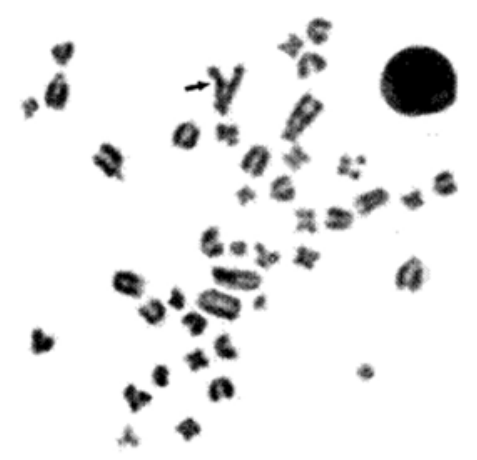

Chromosome gap

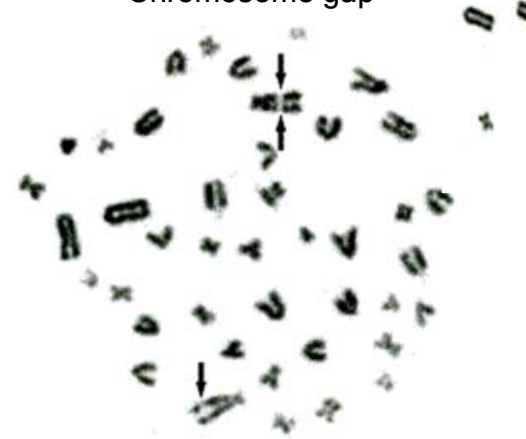

Chromosome break

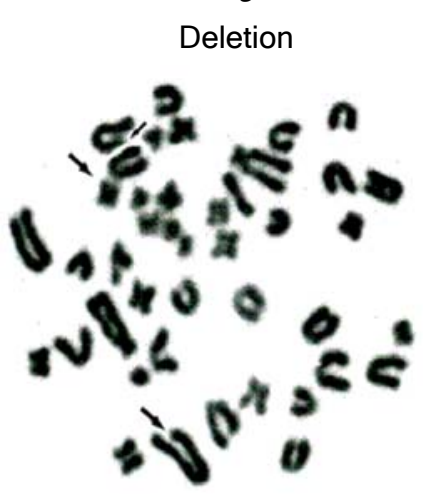

Double Minutes
Vol. 3 No. 6 (June 2010)

ISSN: 0974- 6846
Fig. 3. Chromosome aberration types

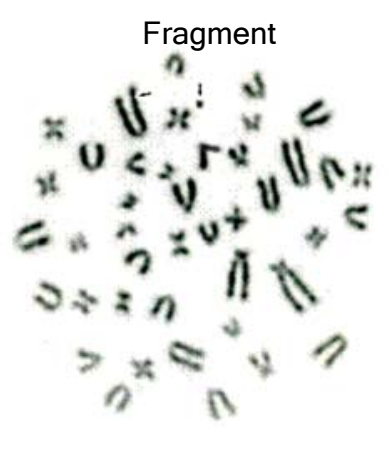

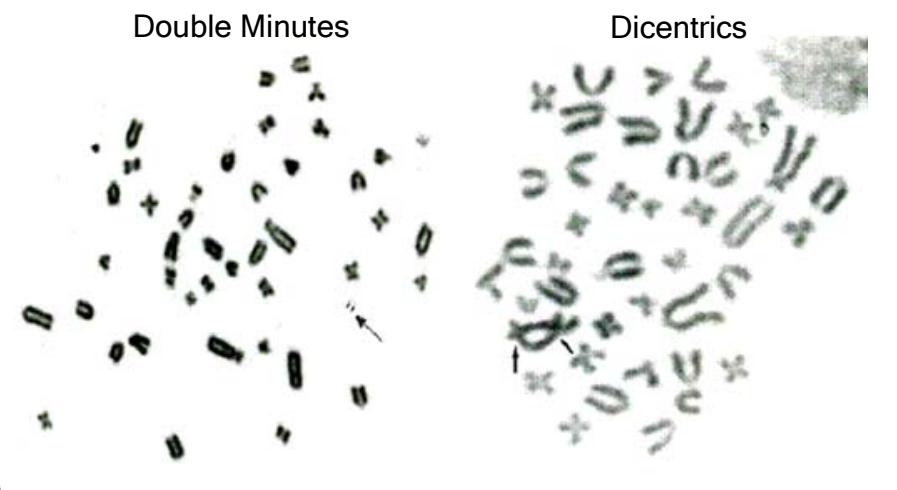

Fig. 4. Chromosome aberration types

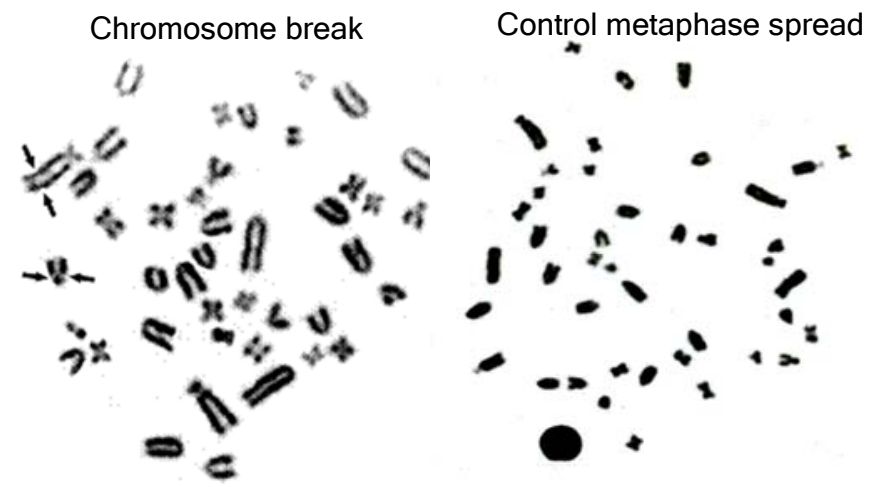

Pulverised metaphase spread

Table 1. Chromosomal aberrations

\begin{tabular}{|l|l|l|l|l|l|c|}
\hline Group & \multicolumn{1}{|c|}{ Chromatid gap } & $\begin{array}{c}\text { Chromosome } \\
\text { gap }\end{array}$ & $\begin{array}{c}\text { Chromatid } \\
\text { breaks }\end{array}$ & $\begin{array}{c}\text { Chromosome } \\
\text { breaks }\end{array}$ & \multicolumn{1}{|c|}{ Deletions } & Fragments \\
\hline Group I & $55.98 \pm 4.4$ & $14.8 \pm 1.47$ & $26.6 \pm 1.63$ & $5.5 \pm 1.04$ & $37.66 \pm 2.6$ & $5.0 \pm 1.41$ \\
\hline Group II & $176.16 \pm 24.6^{\mathrm{a}}$ & $56.33 \pm 7.65^{\mathrm{a}}$ & $192.0 \pm 27.24^{\mathrm{a}}$ & $28.16 \pm 3.6^{\mathrm{a}}$ & $154.0 \pm 21.4^{\mathrm{a}}$ & $13.6 \pm 2.2^{\mathrm{a}}$ \\
\hline Group III & $130.16 \pm 10.26^{\mathrm{b}}$ & $23.6 \pm 1.6^{\mathrm{b}}$ & $84.0 \pm 6.3^{\mathrm{b}}$ & $30.0 \pm 2.3^{\mathrm{a}}$ & $78.66 \pm 6.3^{\mathrm{b}}$ & $11.5 \pm 1.04^{\mathrm{b}}$ \\
\hline Group IV & $126.0 \pm 9.4^{\mathrm{bc}}$ & $30.0 \pm 2.3^{\mathrm{bc}}$ & $98.16 \pm 7.8^{\mathrm{bc}}$ & $36.0 \pm 2.3^{\mathrm{bc}}$ & $116.0 \pm 9.7^{\mathrm{bc}}$ & $5.83 \pm 0.75^{\mathrm{bc}}$ \\
\hline Group V & $83.82 \pm 6.9^{\mathrm{bcd}}$ & $22.3 \pm 1.9^{\mathrm{bcd}}$ & $56.16 \pm 4.7^{\mathrm{bcd}}$ & $14.0 \pm 1.5^{\mathrm{bcd}}$ & $62.0 \pm 4.9^{\mathrm{bcd}}$ & $7.5 \pm 1.04^{\mathrm{bcd}}$ \\
\hline
\end{tabular}

Each value is expressed as mean $\pm S D$ for six rats in each group. ${ }^{a}$ As compared with group $1 ;{ }^{b}$ As compared with group II; ${ }^{c}$ As compared with group III; ${ }^{d}$ As compared with group IV; ${ }^{a, b, c, d}$ represent $p<0.05$

Research article

CIndian Society for Education and Environment (iSee)
"Vitamins to ameliorate arsenic toxicity" http://www.indjst.org

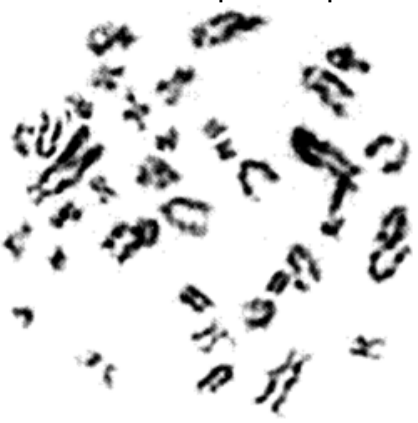




\section{Results}

Chromosomal aberration as observed by metaphase preparation revealed an increase in chromosome gap by $214 \%$, chromatid gap $280 \%$, chromatid break $621 \%$, chromosome break $412 \%$, deletions $308 \%$ and fragments $172 \%$ in group-II animals (rats)treated with arsenic alone. Whereas group- $V$ animals supplemented with antioxidant vitamin $\mathrm{C}$ and vitamin $\mathrm{E}$ showed a remarkable reduction in the types of aberration to $52.41 \%, 60.41 \%, 70.75 \%$, $50.28 \%, 59.74 \%$ and $44.85 \%$ compared to that of group-II (Table 1 \& Fig.1). Moreover a positive correlation was observed between the types of aberrations and the blood concentration level of arsenic. The correlation coefficient ' $r$ ' being 0.97 for chromosome gap, 0.56 for chromosome break, 0.93 for chromatid gap, 0.98 for chromatid break, 0.91 for deletions and 0.83 for fragments. The types of aberrations induced by arsenic have been shown in Fig. 2, $3 \& 4$.

\section{Discussion}

Our observation demonstrated that free radicals might be involved in arsenic induced chromosomal aberration. This is corroborated by a reduction in the formation of these aberrations in groups supplemented with antioxidants such as vitamin $\mathrm{C}$ and vitamin $\mathrm{E}$ (Table 1). Recent studies show that Reactive Oxygen Species (ROS) are involved in arsenite induced cell signaling and activation of transcription factor (Barchowsky et al., 1999) leading to chromosomal aberrations (Hei et al., 1998), DNA strand breakage (Lynn et al., 2000), gene mutation (Hei et al., 1998) generation of micronuclei (Wang \& Huang, 1994; Gurr et al., 1998) and apoptosis (Gurr et al., 1999). Moreover metabolism of arsenic generates oxygen radicals (Kessel et al., 2002; Hei and Filipic, 2004; Valko et al., 2006) which may damage the cellular macromolecules and decrease CytP ${ }^{450}$ biotransformation enzymes involved in xenobiotic metabolism (Albores et al., 1989). Antioxidant Vitamin $\mathrm{E}$ is an important lipid soluble antioxidant present in cells, as it is the major chain terminating antioxidant in biological membranes (Burton et al., 1983) and scavenges a wide array of ROS including ${ }^{1} \mathrm{O}_{2}, \mathrm{HO}^{\circ},{ }^{\circ} \mathrm{O}_{2}{ }^{-}$, Peroxyl, and alkoxyl radicals. Vitamin $\mathrm{E}$ is composed of a number of derivatives of tocopherols and tocotrienols. The major isomer in humans is $\alpha-\mathrm{TOH}$, which also possesses the greatest antioxidant activity of any vitamin $\mathrm{E}$ derivative. In homogenous solutions, $\alpha-\mathrm{TOH}$ is a strong inhibitor of polyunsaturated lipid peroxidation (Samokyszyn et al., 1990) and in vivo, most of the cellular vitamin $E$ is concentrated in the lipid membranes (Bjorneboe et al., 1990). The primary antioxidant activity of tocopherols is to stop chain propagation of peroxyl radicals $\left(\mathrm{k}=6 \times 10^{3}-3\right.$ $\times 10^{6} \mathrm{M}^{-1} \mathrm{sec}^{-1}$ ) (Niki and Matsuo, 1993).

Tocopherol can typically scavenge two ROS per tocopherol molecule (Horswel et al., 1966). Ascorbic acid (Vitamin C), a water soluble antioxidant, exists primarily as ascorbate at physiological $\mathrm{pH}$. Ascorbate is a powerful reducing agent capable of rapidly scavenging a number of ROS including ${ }^{\circ} \mathrm{O}_{2}^{-}\left(\mathrm{k}=2.7 \times 10^{5} \mathrm{M}^{-1} \mathrm{sec}^{-1}\right)$ (Nishikimi, 1975).

In addition, ascorbate reacts with other cellular prooxidants such as ${ }^{1} \mathrm{O}_{2}$, hypochlorous acid (HOCL) and thiol radicals (RS') (Halliwell, 1990); Ascorbate is also able to reduce the vitamin $\mathrm{E}$ derived tocopheroxyl radical $\alpha-\mathrm{TO}^{\circ}$. Through this mechanism, ascorbate in the aqueous phase is able to regenerate membrane-bound $\alpha-T O H$, prolonging the life time of this important antioxidant in the lipid phase and effecting removal of the radical from the lipid to the aqueous phase. In its action as an antioxidant, ascorbate is rapidly oxidized to dehydroascorbate, which shows little antioxidant activity. Dehydroascorbate may be reduced back to ascorbate via GSH-dependent reductase (Sharma and Buettner, 1993). Therefore group $V$ animals supplemented with antioxidant vitamins $E$ and $\mathrm{C}$, showed reduced chromosomal aberrations due to the free radical scavenging effects of vitamins.

The level of, chromosomal aberrations, was found to be elevated in arsenic-alone treated group-II, whereas the group-V supplemented with antioxidant vitamins showed a minimal levels of alteration in the above said parameters suggesting primarily, that toxicity caused by arsenic was mediated by free radicals.

Exposure to arsenic at low doses chronically causes oxidative stress and depletion of vital antioxidants in the cells. The toxicity of arsenic comprises altered membrane properties, loss of cellular functions, macromolecular damage and finally induction of apoptosis. Co-treatment of antioxidant vitamins like vitamin $C$ and vitamin $E$ to arsenic exposed rats may have restored the antioxidant status of the cells and protected them form arsenic induced clastogenicity. Our study corroborated with similar findings of Ramanathan et al. (2005) that the supplementation of ascorbic acid and a-tocopherol modulated arsenic induced apoptosis in rats by improving the cellular antioxidant status and scavenging of free radicals. It also supports the perspective of coadministration of antioxidant vitamins to arsenic-induced toxicity (Karasavvas et al., 2005; Wei et al., 2005; Balakumar et al., 2010). Therefore it is strongly believed that the present vitamins supplementation perspective will have a probable proactive protection to arsenical exposure.

\section{Acknowledgement}

The authors express their thanks to Dr. C. Paneerselvam, Formerly Professor and Head, Dept. of Biochemistry and Dr. P.M. Gopinath, Formerly Professor and Head, Dept. of Genetics, Dr. ALPGIBMS, University of Madras for their guidance and help during the course of this study. The authors thank the University of Madras for the facilities extended to carry out this study. They also thank Dr. V.V.Subramanian, former principal, Swami Satyapriyananda and Swami Atmaghanananda, the former and present secretaries of RKM. Vivekananda College, for their motivation and help. The UGC-FIP
Research article

CIndian Society for Education and Environment (iSee)
"Vitamins to ameliorate arsenic toxicity" http://www.indjst.org
Balakumar et al. Indian J.Sci.Technol. 
Teacher fellowship granted to B.S.Balakumar is gratefully acknowledged.

\section{References}

1. Albores A, Cebrian ME, Bach PH, Connelly JC, Hinton $\mathrm{RH}$ and Bridges JW (1989) Sodium arsenite induced alterations in bilirubin excretion and heme metabolism. J. Biochem. Toxicol. 4, 73-78.

2. Anusuyadevi $\mathrm{M}$, Jayachandran $\mathrm{KS}$ and Paneerselvam C (2008) Role of L-Carnitine and DL-a-Lipoic acid on EEG pattern in aged rat brain. Curr. Trend. Biotechnol. Pharm. 2(2), 277-285.

3. Axelson O (1980) Arsenic compounds and cancer. J. Toxicol. Environ. Health. 6,1229.

4. Balakumar BS, Ramanathan K, Kumaresan S, Suresh $\mathrm{R}$, (2010). DNA damage by Sodium arsenite in experimental rats: ameliorative effects of antioxidant vitamins C and E. Indian J Sci. Technol. 3 (3), 322327.

5. Ballentine R and Burford DD (1957) Determination of metals. Methods Enzymol. 3,1002-1035.

6. Barchowsky A, Dudek EJ, Treadwell MD and Wetterhann KE (1996) Arsenic induced oxidant stress and NF Kappa G activation in cultured aortic endothelial cells. Free Radical Biol. Med. 21, 783790.

7. Barchowsky A, Roussel RR, Klei LR, James PE, Ganju N, Smity KR and Dudek EJ (1999) Low levels of arsenic trioxide stimulate proliferative signals in primary vascular cells without activating stress effector pathways. Toxicol. Appl. pharmacol. 159, 6575.

8. Bjorneboe A, Bjornenoe GE and Drevon CA (1990) Absorption, transport and distribution of vitamin E. $J$. Nutr. 120, 233-242.

9. Burton GW, Joycen A and Ingold KU (1983) Is vitamin $E$ the only lipid soluble, chain-breaking antioxidant in human blood plasma and erythrocyte membranes? Arch. Biochem. Biophys. 221, 281-290.

10.Cebrian M, Finkelman J, Correy $G$ and Calderon $R$ (1993) Heavy Metals in: Environmental Epidemiology (eds). A project for Latin America and the Caribbean metepec, Mexico: Pan American Centre for Human Ecology and Health, WHO. pp: 95-145.

11.Chen CJ, Hsu LI, Wang CH, Shih WL, Hsu YH, Tseng MP, Lin YC, Chou WL, Chen CY, Lee CY, Wang LH, Cheng YC, Chen CL, Chen SY, Wang YH, Hsueh YM, Chiou HY and Wu MM (2005) Biomarkers of exposure, effect, and susceptibility of arsenic-induced health hazards in Taiwan. Toxicol. Appl. Pharmacol. 206(2), 198-206.

12.Gamble MV, Liu X, Ahsan H, Pilsner R, llievski V, Slavkovich V, Parvez F, Levy D, Factor-Litvak P and Graziano JH (2005) Folate, homocysteine, and arsenic metabolism in arsenic-exposed individuals in Bangladesh. Environ. Health Perspect. 113(12), 1683-1688.
Vol. 3 No. 6 (June 2010)

ISSN: 0974- 6846

13.Gibson RS and Gage LA (1982) Changes in hair arsenic levels in breast and bottle fed infants during the first year of infancy. Sci. Total Environ. 26, 33.

14.Goyer RA, Cherian MG, Jones MM and Reigart JR (1995) Role of Chelatingagents for prevention, intervention and treatment of experimental toxic agents. Environ. Health Perspect. 105, 1048-1052.

15. Gurr JR, Bau DT, Liu F, Lynn S and Jan KY (1999) Dithiothreitol enhances arsenic trioxide induced apoptosis in NB4 cells. Mol. Pharmacol. 56, 102-109.

16.Gurr JR, Liu F, Lynn S and Jan KY (1998) Calciumdependent nitric oxide production is involved in arsenite-induced micronulei. Mutat. Res. 416, 137148.

17. Halliwell B (1990) How to characterize a biological antioxidant. Free Radical Res. Commun. 9, 1-32.

18. Hei TK and Filipic M (2004) Role of oxidative damage in the genotoxicityof arsenic. Free Radical Biol. Med. 37(5), 574-581.

19. Hei TK, Liu SX and Waldren C (1998) Mutagenecity of arsenic in mammalian cells: Role of reactive oxygen species. Proc. Natl. Acad. Sci. 95, 8103-8107.

20. Hood RD, Vedel-Macrander GC, Zaworotko MJ, Tatum FM and Meck RG (1987) Distribution, metabolism and fetal uptake of pentavalent arsenic in pregnant mice following oral or intra peritoneal administration. Teratology. 35, 19.

21. Horswel EC, Howard JA and Ingold KU (1966) Alphatocopherol. Can. J. Chem. 44, 985-991.

22.IARC (International Agency for Research on Cancer) (1987) In IARC monograph on the Evaluation of Carcinogenic risk to humans-overall evaluation of carcinogenicity. An update (eds.,) IARC Monographs 1-42 (supp. 7), International Agency for Research on Cancer Lyon. pp:100.

23. Karasavvas N, Carcamo JM, Stratis G and Golde DW (2005) Vitamin C protects HL60 and U266 cell from arsenic toxicity. Blood. 105(10), 4004-4012.

24. Kessel M, Liu SX, Xu A, Santella R and Hei TK (2002) Arsenic induces oxidative DNA damage in mammalian cells. Mol. Cell Biochem. 234-235(1-2), 301-308.

25. Lee TC, Lee KC, Tzeng YJ, Hung RY and Jan KY (1986) Sodium arsenite potenitates the clastogenicity and mutagenicity of DNA crosslinking agents. Environ. Mutagen. 8, 19-128.

26. Lee TC, Tseng SF, Chang YC, Lin KY and Jan MR (1996) Post treatment with sodium arsenite during G2 enhance the frequency of chromosomal aberrations induced by S-dependent clastogens. Mutat. Res. 163, 263-269.

27.Liu SX, Davidson MM, Tang X, Walker WF, Athar M, Ivanov $V$ and Hei TK (2005) Mitochondrial damage mediates genotoxicity of arsenic in mammalian cells. Cancer Res. 65(8), 3236-3242.

28. Luo ZD, Zhang YM, Ma L, Zhang ZY and He L (1997) Chronic arsenicism and cancer in inner Mangolia consequences of well-water arsenic level greater
Research article

CIndian Society for Education and Environment (iSee)
"Vitamins to ameliorate arsenic toxicity" http://www.indjst.org
Balakumar et al. Indian J.Sci.Technol. 
than $50 \mathrm{mu} / \mathrm{l}$. In: Arsenic exposure and health effects (Abernathy co., Claderon RC, Chappell WR, eds.) London: Chapman \& Hall. pp:55-68.

29. Lynn S, Gurr JR, Lai HT and Jan KY (2000) NADH oxidase activation is involved in arsenite-induced oxidative DNA damage in human vascular smooth muscle cells. Cir. Res. 86, 514-519.

30. Mazumdar DNG, Chakraborty AK, Ghose A, Gupta JD, Chakraborty DP and Dey SB (1988) Chronic arsenic toxicity from drinking water in rural West Bengal. Bull. World Health Org. 66, 499-506.

31. Miller DA, Dev VG, Burek C and Miller OJ (1972) The quinacrine fluorescent and Giemsa banding karyotype of the rat, Rattus norvegicus and banded chromosome analysis of transformedm and malignant rat liver cell lines. Cancer Res. 32, 2375-2382.

32. Niki E and Matsuo M (1993) Rates and products of reactions of vitamin $E$ with oxygen radicals In:Vitamin $E$ in health and disease (Packer L, Fuchs J, eds.) NY: Dekker. pp:121-130.

33. Nishikimi M (1975) Oxidation of ascorbic acid with superoxide anion generated by the xanthine-xanthine oxidase system. Biochem. Biophys. Res. Commun. 63, 463-468.

34.NRC-National Research Council (1999) Chemistry and analysis of arsenic species in water, food, urine, blood, hair and nails. In: Arsenic in drinking water (National Research Council, eds.), National Academy Press, Washington, DC. pp:27-82.

35. Okui $T$ and Fujiwara $Y$ (1986) Inhibition of human excision DNA repair by inorganic arsenic and the co-mutagenic effect of C79 Chinese hamster cells. Mutat Res.172, 69-76.

36. Osborne ED (1925) Microchemical studies of arsenic in arsenical pigmentation and keratoses. Arch. Dermal Syph. 12, 773.

37.Rahman MM, Sengupta MK, Ahamed S, Lodh D, Das B, Hossain MA, Nayak B, Mukherjee A, Chakraborti D, Mukherjee SC, Pati S, Saha KC, Palit SK, Kaies I, Barua AK and Asad KA (2005) Murshidabad-one of the nine groundwater arsenic-affected districts of West Bengal, India. Part I: magnitude of contamination and population at risk. Clin. Toxicol. (Phila). 43(7), 823-834.

38. Ramanathan K, Anusuyadevi $M$, Shila $S$ and Panneerselvam C (2005) Ascorbic acid and alpha tocopherol as potent modulators of apoptosis on arsenic induced toxicity in rats. Toxicol. Lett. 156(2), 297-306.

39. Rich $\mathrm{CH}$, Biggs $\mathrm{ML}$ and Smith $\mathrm{AH}$ (1998) Lung and kindey cancer mortality associated with arsenic in drinking water in Cordoba, Argentina. Int. J. Epidemiol. 27, 561-569.

40.Roy P and Saha A (2002) Metabolism and toxicity of arsenic: A human carcinogen. Curr. Sci. 82(1)38-45.

41.Samokyszyn VM, Miller DM, Reif DW and Aust SD (1990) Iron-catalyzed lipid peroxidation. In:
Membrane lipid oxidation, Vol. 1(Vigo-Pelfrey C.ed.). Boca Raton, FL: CRC Press. pp:101-127.

42.Sharma AK and Sharma A (1994) Chromosome techniques: A manual. Switzerland: Harwood Academic publishers.

43. Sharma MK and Buettner GR (1993) Interaction of vitamin $C$ and vitamin $E$ during free radical stress in plasma: an ESR study. Free Radical Biol. Med. 14, 649-653.

44.Shaw WD, Walker M and Benson M (2005) Treating and drinking well water in the presence of health risks from arsenic contamination: results from a U.S. hot spot. Risk Anal. 25(6), 1531-1543.

45.Smith AH, Goycolea M, Haque R and Biggs ML (1998) Marked increase in bladder and lung cancer mortality in a region of northern Chile due to arsenic in drinking water. Am. J. Epidemiol. 147, 660-669.

46. Stocken LA and Thompson RHS (1946) Arsenic derivaties of thiol proteins. Biochem. J. 40, 548.

47.Tseng $\mathrm{CH}$, Huang YK, Huang YL, Chung CJ, Yang $\mathrm{MH}$, Chen CJ and Hsuch YM (2006) Arsenic exposure, urinary arsenic speciation, and peripheral vascular disease in blackfoot-disease hyper-endemic villages in Taiwan. Toxicol. Appl. Pharmacol. 211(2), 175.

48. Unakul W and Hsu TC (1977) The C- and G-banding patterns of Rattus norvegicus Chromosomes. J. Natl. Cancer Instt. 49, 1425-1431.

49.USEPA (United states Environmental protection Agency) (2001) National Primary Drinking water regulations: Arsenic and Clarifications to compliance and new source contaminants monitoring: Final rule (40 CFR Part 9, 142 \& 142) fed. Reg. 66, 6975-7066.

50. Valko M, Rhodes CJ, Moncol J, Izkovic M and mazur M (2006) Free radicals, metals and antioxidants in oxidative stress-induced cancer. Cancer Res. 160(1), $1-40$.

51.Wang TS and Huang $\mathrm{H}$ (1994) Active oxygen species are involved in the induction of micronuclei by arsenite in XRS-5 cells, Mutgenesis. 9, 253-257.

52. Wei M, Arnold L, Cano M, Cohen SM. (2005) Effects of co-administration of antioxidants and arsenicals on the rat urinary bladder epithelium. Toxicol. Sci. 83(2), 237-245.

53. Welch AH, Lico MS and Huges JL (1998) Arsenic in ground water of the western United States. Ground Water. 26, 33-337.

54.WHO (World Health Organization) (1981) Environmental health criteria- arsenic, Geneva.

55.WHO (World Health Organization) (1993) Guidelines for drinking water quality Vol. 1: Recommendations. $2 d$ eds., Geneva.

56. Yamauchi H and Fowler BA (1994) Toxicity and metabolism of inorganic and methylated arsenicals. In arsenic in the environment, Part II: Human health and ecosystem effects. Nriagu JO (ed.), Wiley, NY. pp:35-43.
Research article

CIndian Society for Education and Environment (iSee)
"Vitamins to ameliorate arsenic toxicity" http://www.indjst.org
Balakumar et al. Indian J.Sci.Technol. 